\title{
The Use of Information and Communication Technologies in Education
}

\author{
PhD. Cand. Arti Omeri \\ Department of English Language and Literature, \\ Faculty of Philology and Education, Bedër University, Tirana, Albania
}

\begin{abstract}
The technology is developing very fast in all aspects of life. Information and Communication Technologies as part of it are being introduced with a high impact in the lives of human beings. As a result they also play an important role in education. This research is focused on new communication technologies in education as it is a highly discussed topic nowadays. Then the most modern literature on the topic was analyzed. After reviewing the literature and giving credit to main theories, a questionnaire was conducted in three universities in Albania. Firstly it was conducted at two state universities in Tirana and Elbasan. Then it was conducted at a private university that uses the most modern technology in teaching. The questionnaire included both open ended and closed ended questions. Being a lecturer in two out of these three universities gave me the possibility to conduct the survey personally without much difficulty and in a relatively short period. These universities were chosen in order to evaluate the importance of using Information and Communication Technologies in education. Also it was very interesting to compare the benefits of using such technologies. Although all three universities are located in the same country the inequalities are easily visible. At the end of the study there are given suggestions in order to find the ways to improve the education system through using Information and Communication Technologies.
\end{abstract}

Keywords: Information and Communication technology, internet, Computer, Videoconferencing, Education system.

\section{Introduction}

In the globalized world that we are living the technology is improving and changing rapidly. Like in other fields of life, even in education the use of Information and Communication Technology is becoming very important. There is a lot of pressure nowadays on education to adapt to a technically driven society and to implement the ICT (Kaufman, K. 2014, P. 2). Information and Communication Technology is seen as a possibility to introduce the education process even in the areas and social groups that are currently excluded from education.

The term Information and Communication Technology can be defined as a diverse set of tools and resources used to communicate and to create, disseminate, store and manage information. These technologies include computers, the internet, radio broadcasting (radio and television) and telephony technologies (Blurton, C. 1999 as cited in Mocanu (Dedu), E. m., \& Deaconu, A. a; 2017, P 19). Trifonova, M. claims that computers and the telecommunication means can increase the analytical opportunities and are an indispensible part of the daily life of people from different professions (Trifonova, $M$. 2013, P. 295). ICT is not limited only to computers and internet. Older technologies such as radio, television and telephone have long been used as instructional tools even though their importance has declined in recent periods. The use of computers and internet is not spread equally in all the countries due to lack of infrastructure and high costs (C. Zhou1, C., Purushothaman, A. a., \& Rongbutsri, N. n. 2013, P. 51)

According to Mocanu (Dedu), E. m., \& Deaconu, A. a. "In most countries in Europe, the use of ICT tools in the educational process has become crucial in order to modernize services, improve teachers' skills and increase student performance "( Mocanu (Dedu), E. m., \& Deaconu, A. a. 2017, P. 20). The use of ICT can also improve the quality and the efficiency of learning. In their study Sungsup Ra1, s., Brian, C., \& Cher Ping, L. claim that when ICT-based teaching and learning resources are available, students can have better access to quality information and at the same time they can increase the learning opportunities whether in school or outside it. Integrating ICT can make lifelong learning more efficient (Sungsup Ra1, S., Brian, C., \& Cher Ping, L. 2016, P. 75). Regarding the effect that ICT has on the quality of education, Nnoduka 
Olele, C. describes it as a force that can improve quality education services as it allows learners to reach their fullest potential ( Nnoduka Olele, C. 2014, P. 115).

Many scholars have focused on the benefits that access to ICT can have on education. In their study Phiri, A. C., foko, T., \& Mahwai, N. mention 13 benefits and they are as the following:

" (i) expanding the reach and equity of education (ii) facilitating personalised learning; (iii) powering anywhere, anytime learning; (iv) providing immediate feedback and assessment; (v) Ensuring the productive use of time spent in classrooms; (vi) building new communities of learners; (vii) Supporting situated learning; (viii) Enhancing seamless learning; (ix) Bridging formaland informal learning; (x) Minimising education disruption in conflict and disaster areas; (xi) Assisting learners with disabilities; (xii) Improving communication and administration; (xiii) Maximising cost efficiency " (Phiri, A. C., foko, T., \& Mahwai, N. 2014, P. 64).

As it can be seen there are numerous benefits or advantages of using ICT in education. Other scholars have added other benefits to that long list. In his study Udochukwu Njoku, C. P. among other benefits has focused on the interaction with the students. ICT provide lecturers the possibility to interact with the students anytime and anywhere they are outside the semester (Udochukwu Njoku, C. P. 2015, P. 125). In addition it can help lecturers and academic designers identify their planned teaching delivery model for course provision (Caird, S. s., \& Lane, A. 2015, P. 65). Gärdenfors, P., \& Johansson, $P$. argue that using ICT does not necessarily mean that many problems in education would be solved as people used to believe some year ago. The main concern is whether these tools really improve the way how the students learn (Gärdenfors, P., \& Johansson, P. 2005, P. 1). Aviram, R., \& Richardson, J. in their study state that although many institutions have joined the online teaching, they are continually using the conventional methods of instruction (Aviram, R., \& Richardson, J. 2005, P. 30).

According to Gwang-Jo Kim there are five areas of education in which ICT can be included. It can be included as a subject; as a tool in the learning process; as an administrative tool; as an expanded learning opportunity; as a facilitator (Gwang-Jo Kim 2009, as cited in Nnoduka Olele, C. 2014, P. 116). Chisalita, O. O. states that "In the contemporary education, the presence and the use of the technology make the difference between schools that train students to integrate into the society and schools which only focus on the training with no purpose related to their integration" (Chisalita, O. O. 2013, P. 70).

\section{Method}

This research was conducted in three universities in Albania. Two of them, "Aleksander Xhuvani" and University of Tirana are public universities, whereas "Beder" is a private university located in Tirana. Being a lecturer at "Beder" and "Aleksander Xhuvani" universities gave me the opportunity to conduct the questionnaire personally without any difficulties or limitations. At Tirana University a lecturer of that university accompanied and helped me during this process. The questionnaire was composed of ten questions including open ended and closed ended questions. At "Beder" and "Aleksander Xhuvani" the questionnaires were distributed to the bachelor students of Education Departments, whereas at Tirana University the questionnaires were distributed to the students of Foreign Language Faculty. In all three universities there were asked the same questions and there were given a few instructions on how to fill the questionnaires. The aim and the anonymity of the questionnaires were also explained. In total there were distributed 100 questionnaires in three different universities.

The questionnaire included questions on students' perception on ICT. How they could define ICT and what can be included in it? Other questions asked whether ICT is used in their institutions and to what extent? Also suggestions and opinions were asked from students in order to improve the learning process through ICT.

The first two state universities were chosen for this study as they are larger, older and have invested a lot of funds for their infrastructure compared to other Albanian state universities. On the other hand Beder is one of the private universities which has invested a lot in technology and considers ICT as an important element in education. So, comparing these three universities would be important in order to find out the real situation in main Albanian universities where the majority of students are enrolled.

\section{Results}

When compared to each other the results of the study differ for all three universities. In general most of the students in all universities had a good perception about ICT. Students at "Beder" mentioned internet, computers, e-learning, emails, videoconferences, BIS system and mobile phones as part of ICT. Similar devices were mentioned from students of the 
other two state universities. $85 \%$ of students at "Beder" claimed that they use these devices regularly in their institution and they were satisfied from them. At Tirana University the percentage drops to $50 \%$ and at "Aleksander Xhuvani" only $35 \%$ of students use ICT regularly during the learning process.

It should be noted that the number of students who use ICT outside the classroom increases significantly at state universities. Over $80 \%$ of students make use of ICT outside classroom. At private university there were no significant differences in percentages for the use of ICT in the classroom and outside it. Most students, $90 \%$ at state universities and $70 \%$ at private university, agreed that ICT should be used more in their education system.

Regarding the benefits of ICT in education the vast majority of students, over $85 \%$, in all universities were in complete accordance. They saw ICT as very useful and beneficial in the education system. Convenience, efficiency and equity in education were some of the main benefits mentioned by the students. To lesser extents, also interaction and time management were also given as benefits from ICT use in education.

When asked about opinions and suggestions in order to improve the learning process through ICT students gave several ideas. Students think that ICT should be continually used and should always be adapted to the new technological changes. The institutions should introduce more ICT devices. Students and lecturers should be trained on how to use certain devices and programs. Some students claimed that they were asked to make certain kinds of presentations or projects even though they did not have any previous training on how to prepare them. Another problem to overcome in state universities was that although same classrooms have computers, internet and projectors, they are not easily accessed by the students. Maintenance of ICT related devices was also considered a priority from students of all three universities. Once they are introduced, there should be someone to take care and repair them.

\section{Discussion}

As it is seen from the results of the questionnaire students had a good perception of ICT and valued it positively. Although the results were relatively different in certain questions, when it comes to benefits students from all three universities agreed that ICT can have a lot of benefits once it is introduced in education. The positive impact of ICT in education is widely recognized by various researchers. As it was already discussed in this study many scholars have mentioned and focused on benefits of ICT in education. Among others they have focused on efficiency and equity as two of the most important benefits of it.

As it was mentioned above in their study Sungsup Ra1, s., Brian, C., \& Cher Ping, L. claim that when ICT-based teaching and learning resources are available, students can have better access to quality information and at the same time they can increase the learning opportunities whether in school or outside it. Integrating ICT can make lifelong learning more efficient (Sungsup Ra1, s., Brian, C., \& Cher Ping, L. 2016, P. 75). The results of the study support such theories. Two out of the three most mentioned ICT benefits from students were equity and efficiency. The other most mentioned benefit in the study was convenience.

In addition the results of the students showed that interaction and time management were also benefits from ICT use in education. These results are in accordance with studies from other scholars. In his study Udochukwu Njoku, C. P. among other benefits has focused on the interaction. According to him ICT provide lecturers the possibility to interact with the students anytime and anywhere they are outside the semester (Udochukwu Njoku, C. P. 2015, P. 125).

\section{Conclusion}

The use of ICT is becoming increasingly important in education. It can have a lot of benefits and advantages in the learning process. In Albanian universities ICT is currently being implemented in education system although the percentages differ from one university to another. In the private university they are used more than in state universities, but even between the two state universities there was a significant difference. The study found that students had a good perception on ICT and they knew most of the devices or programs that can be included in it. An interesting finding of the study was that in state universities students use ICT more outside the classroom. The results of the study did not show the same difference in the private university. It means that private universities are better equipped with ICT and their students can easily access them.

To conclude it should be said that ICT should be continually used and should always be adapted to the new technological changes. In some institutions of higher education there is still a lack of ICT devices. In these institutions, the government and local authorities should introduce and invest more on ICT devices. Students and lecturers should be trained on how to 
use certain devices and programs. It is the duty of authorities in different universities to organize these training programs. Maintenance of ICT related devices should also be taken into consideration as there were found many problems in that regard.

\section{Bibliography}

[1] Aviram, R., \& Richardson, J. (2005). Upon What Does the Turtle Stand? : Rethinking Education for the Digital Age. New York: Springer.

[2] Caird, S. S., \& Lane, A. (2015). Conceptualising the role of information and communication technologies in the design of higher education teaching models used in the UK. British Journal Of Educational Technology, 46(1), 58-70. doi:10.1111/bjet.12123

[3] Chisalita, O. O. (2013). New Educational Literacies. Changes Brought By The Information And Communication Technologies (Ict's) In Education. Elearning \& Software For Education, (1), 70-73. doi:10.12753/2066-026X-13010

[4] C. Zhou1, c., Purushothaman, A. a., \& Rongbutsri, N. n. (2013). Facilitating Sustainability of Education by Problem-Based Learning (PBL) and Information and Communication Technology (ICT). International Journal Of Emerging Technologies In Learning, 8(6), 50-54. doi:10.3991/ijet.v8i6.3146

[5] Gärdenfors, P., \& Johansson, P. (2005). Cognition, Education, and Communication Technology. Mahwah, N.J.: Routledge.

[6] Kaufman, K. (2014). Information Communication Technology: Challenges \& Some Prospects from Pre-Service Education to the Classroom. Mid-Atlantic Education Review, 2(1), 1-11.

[7] Mocanu (Dedu), E. m., \& Deaconu, A. a. (2017). The Use Of Information And Communication Technology (Ict) As A Teaching Method In Vocational Education And Training In Tourism. Acta Didactica Napocensia, 10(3), 1934.

[8] Nnoduka Olele, C. (2014). Manpower Development For Information And Communication Technologies (Icts) Integration In Education. Journal Of Business \& Educational Leadership, 5(1), 113-126.

[9] Phiri, A. C., foko, T., \& Mahwai, N. (2014). Evaluation of a Pilot Project on Information and Communication Technology for Rural Education Development: A Cofimvaba Case Study on the Educational Use of Tablets. International Journal Of Education And Development Using Information And Communication Technology, 10(4), 60-79.

[10] Sungsup Ra1, s., Brian, C., \& Cher Ping, L. (2016). A holistic approach towards Information and Communication Technology (ICT) for addressing education challenges in Asia and the Pacific. Educational Media International, 53(2), 69-84. doi:10.1080/09523987.2016.1211334

[11] Trifonova, M. (2013). Necessity For Checking The Entrance Level At Information And Communication Technologies (Ict) Of Students Of Education. Trakia Journal Of Sciences, 11(3), 294-297.

[12] Udochukwu Njoku, C. P. (2015). Information and communication technologies to raise quality of teaching and learning in higher education institutions. International Journal Of Education \& Development Using Information \& Communication Technology, 11(1), 122-147. 